The remaining German books are pamphlets dealing with particular questions which appeared important during the seventeenth century. One pamphlet appearing in 1624 dealt with the question of whether a debtor who had received gold standard coins of the realm could repay his debt in debased coinage and the author quotes imposing Latin passages to support his thesis that one should not. Another treatise appearing in I623 contains the "kurzes aber doch gründlichs Bedencken" on whether a man who had purchased a yearly pension could be expected to accept the same money which has since depreciated. A fourth pamphlet also treats of these monetary problems.

The most valuable book of this group is an expression of English mercantilism written at the height of this theory's popularity. It is, according to the unknown author, "A Discourse of Trade, Coyn, and Paper Credit: and of Ways and Means to Gain, and Retain Riches." Nations may be considered as great families, or merchants, or traders in their relations with one another. If one nation does not export goods in payment for goods imported, then as in the trade among individuals, there must be a movement of bullion. Those trades are good which encourage exports, those dis. advantageous which cause imports. The author admits gold and silver are only commodities which "cannot afford us any increase while kept within the Kingdom" yet he insists that it is "that in which the Riches of Nation doth so much consist" and vaguely substantiates this remark with the statement that gold and silver are "so necessary for the Payment of Fleets and Armies, and carrying on of Commerce, that we cannot be Safe, nor Rich, without it."

\title{
Evidence of the Putting-Out System in America
}

AN old hand-worn brown leather book has come into the hands of the Business Historical Society on the varied business activities of a New Englander for the period 1837 to 1857 . We are indebted to Edgar A. Clarke of New Hartford, Connecticut, for this rarity.

Anthony Baker, who kept the book, evidently began his career as a tanner and mâker of leather goods. Hides were probably brought in by the neighboring farmers to New Hartford, and boots, 
harnesses and other leather articles were made to satisfy the individual orders of the community.

The first half of the Baker records is a daybook on his activities in this business. A pair of thick boots for Julius Dailey was $\$ 2.75$. Soling a pair of women's boots was $\$ .17$. A pair of boy's shoes cost $\$ 2.00$. Soling and heeling a pair of boots were $\$ .62$. Luman Callin had a calfskin tanned for $\$ .75$. Baker includes his own accounts and we find him paying $\$ 3.48$ for 87 pounds of hide. Each scribbled item is marked debit or credit to show incoming or outgoing cash.

The latter half of the book is a ledger. Some time before $185^{\circ}$ Baker had expanded his business horizontally. He had taken a two-story building - the first floor of which was used as a general store and post office, while the second story housed his growing clothing factory. Much of the business was done on the puttingout system and the ledger contains the names and accounts of over a hundred women - wives of farmers - who did handwork on the garments in their homes. For work on overalls - not described in the ledger - the women were invariably paid $\$ .75$ per dozen. Work on coats - which in many cases consisted of partially lining them - was paid at the rate of $\$ .25$ per coat. The women seemed to earn about $\$ 1.50$ or $\$ 2.00$ a month with decreases during the summer canning season and increased amounts during the winter months.

That Mr. Baker was in a somewhat advantageous position one discovers in the book notations of "cash" and "order." The latter, of course, means that the payment to the employees took the form of store supplies - and this form of payment seems to have dominated Baker's relations with his employees.

Mrs. Gibbs, for example, seems to have been one of his most industrious workers. From May 8 to November 5, 1857 the lady earned the tremendous sum of $\$ 70.00$. On November 18 she was paid, receiving \$49.26 as "order" and the remaining amount in cash. It is a significant point but under the circumstances rather profitless, to consider whether Mrs. Gibbs in the ecstasy of receiving a fortune, desired or was persuaded to purchase "two cans of everything you have, Mr. Baker, with a broom thrown in and maybe some more bottles of ketchup."

At any rate the small tanning business of 1825 had become by I 855 one worth $\$ 20, \infty 00$ in a small town in northwestern Connecticut. 